\title{
Influence of Arsenate and Phosphate on the Regulation of Growth and TCA Cycle in the Rice (Oryza sativa L.) Cultivars IR64 and Nayanmani
}

\author{
Jayeeta Saha, Madhushree Dutta, Asok K. Biswas*
}

Plant Physiology and Biochemistry Laboratory, Centre of Advanced Study, Department of Botany, University of Calcutta, Kolkata, India

Email: *asokbiswas2016@yahoo.com

How to cite this paper: Saha, J., Dutta, M. and Biswas, A.K. (2017) Influence of Arsenate and Phosphate on the Regulation of Growth and TCA Cycle in the Rice (Oryza sativa L.) Cultivars IR64 and Nayanmani. American Journal of Plant Sciences, 8, 1868-1887.

https://doi.org/10.4236/ajps.2017.88127

Received: June 15, 2017

Accepted: July 17, 2017

Published: July 20, 2017

Copyright ( 92017 by authors and Scientific Research Publishing Inc. This work is licensed under the Creative Commons Attribution International License (CC BY 4.0).

http://creativecommons.org/licenses/by/4.0/ (c) (i) Open Access

\begin{abstract}
The influence of arsenate and phosphate on the growth and respiration of 21 days old seedlings in two cultivars of rice, viz., IR64 and Nayanmani was studied. As arsenate and phosphate are similar in their chemical configuration and the latter is preferentially taken up by the phosphate transporters, it results in a competitive inhibition of arsenate uptake in presence of phosphate. Increasing concentrations of sodium arsenate $(25 \mu \mathrm{M}, 50 \mu \mathrm{M}$ and $100 \mu \mathrm{M})$ hindered the growth in both the cultivars, with cv. IR64 being more severely affected than cv. Nayanmani. There was an elevation in the levels of organic acids measured in both the cultivars, accompanied by a reduction in the activities of the dehydrogenases of the TCA cycle, viz., pyruvate dehydrogenase, isocitrate dehydrogenase, succinate dehydrogenase and malate dedrogenase under arsenic treatment alone. Also, an elevation in the activities of citrate synthase and fumarase enzymes was noticed in both test seedlings with increasing concentrations of arsenic. These alterations were more prominent in cv. IR64 than in cv. Nayanmani. On joint application of phosphate along with arsenate, amelioration of the toxic effects of arsenate was observed to some extent, resulting in an overall revival of respiration leading to improved growth and metabolism.
\end{abstract}

\section{Keywords}

Arsenic, Phosphate, Respiration, Rice, TCA Cycle, Amelioration

\section{Introduction}

Groundwater arsenic contamination leading to toxicity in plants, animals and humans has become a major concern in the last few decades [1]. In parts of In- 
dia and Bangladesh, drinking water can contain more than $50 \mu \mathrm{g} / \mathrm{L}$ of arsenic, while the concentration of arsenic may be as high as $400 \mu \mathrm{g} / \mathrm{L}$ in the rice fields [2] owing to the use of arsenic contaminated groundwater for irrigation. Rice, the major staple food crop of half the world's population is particularly efficient in accumulating arsenic from the soil and hence poses a major risk to human health.

Arsenic is present in the environment in various forms; the major biologically important species are arsenite (As III) and arsenate (As V) [3]. Arsenic shows various phytotoxic effects like stunted shoot and root growth, yellowing of leaves [4] along with reduction in the photosynthetic capacity of the cell [5]. This is the result of reaction of pentavalent and trivalent arsenic radicals with the sulfhydryl groups and replacement of phosphate from ATP [6].

The TCA cycle is a series of chemical reactions used by aerobic organisms to generate energy. Till date, very few reports exist on effect of arsenic on respiration in plants, although it has been reported that heavy metals like cadmium, copper and lead affected the respiration in plants considerably. Studies on the cell membrane ultrastructure of tobacco leaves by [7] showed that Cd toxicity altered respiration by damaging the mitochondrion cristae. Moreover, it was found that both copper and lead adversely affected the seed germination and respiratory rates in soyabean and rice respectively [8] [9].

Many experiments have co-related the production of organic acids to abiotic stress tolerance in plants. Functions of organic acids, especially TCA cycle intermediates are manifold, ranging from assisting with nutrient deficiencies, metal tolerance and plant-microbe interactions at the soil-root interphase to being involved in varied biochemical pathways like production of energy and formation of precursors for amino acid biosynthesis [10].

Pyruvate, which is yielded as a result of glycolysis, is decarboxylated by the enzyme pyruvate dehydrogenase (PDH) (EC 1.2.4.1) forming acetyl coenzyme A which then enters the TCA cycle. In the next reaction the enzyme citrate synthase (CS) (EC 2.3.3.1) combines the acetyl group of acetyl-CoA with a fourcarbon dicarboxylic acid (oxaloacetate, OAA) to give a six-carbon tricarboxylic acid (citrate) [11]. Other important steps in the cycle are conversion of isocitrate to a-ketoglutarate catalyzed by isocitrate dehydrogenase (ICDH) (E.C. 1.1.1.41), succinate to fumarate catalyzed by succinate dehydrogenase (SDH) (E.C. 1.3.5.1) with the generation of energy in the form of $\mathrm{FADH}_{2}$ and malate to oxaloacetate catalyzed by malate dehydrogenase (MDH) (E.C. 1.1.1.37). Fumarase (E.C. 4.2.1.2.) catalyses the reversible hydration of fumarate to malate, one of the constituent reactions of the tricarboxylic acid (TCA) cycle [12].

Phosphorus $(\mathrm{P})$ is one of the essential elements required for plant growth and is a chemical analogue of arsenic as both the elements belong to group $\mathrm{Va}$ of the periodic table. Because of the similarity in their chemical structure, As and $\mathrm{P}$ compete for the same uptake carriers in the plants [13]. Studies indicate that addition of $\mathrm{P}$ resulted in reduced uptake of As in arsenic tolerant plants like Holcus lanatus, Cystisus striatus [14] [15] as well as in Brassica juncea [16]. 
In order to understand the alterations due to application of arsenic with or without phosphate on the overall growth and metabolism of rice seedlings it is imperative that we investigate the effects on the key enzymes and the substrates of the respiratory cycle. By joint application of phosphate along with arsenate, we tried to combat the critical problem of groundwater arsenic toxicity in rice. Such studies will help to devise a cost effective and farmer friendly way to overcome the present situation by application of phosphate enriched fertilizers in arsenic contaminated rice fields.

\section{Plant Material and Arsenic Treatments}

Rice (Oryza sativa L.) seeds cv. Nayanmani and cv. IR64 and obtained from the State Rice Research Station, Chinsurah, Hoogly, West Bengal, were surface sterilized with $\mathrm{NaOCl}(5 \% \mathrm{~W} / \mathrm{V})$ and washed thoroughly. The petridishes $(\phi 10 \mathrm{~cm})$ were lined with filter papers contained about 75 - 80 seeds for each treatment. After germination in dark and humid condition for 72 hours at $30^{\circ} \mathrm{C} \pm 2^{\circ} \mathrm{C}$ the seedlings were exposed to various concentrations $(25 \mu \mathrm{M}, 50 \mu \mathrm{M}, 100 \mu \mathrm{M})$ of sodium arsenate $\left(\mathrm{Na}_{2} \mathrm{HAsO}_{4} \cdot 7 \mathrm{H}_{2} \mathrm{O}\right.$; Loba-Chemie, India) solution (w/v) with or without $2 \mathrm{mM}$ potassium dihydrogen orthophosphate $\left(\mathrm{KH}_{2} \mathrm{PO}_{4}\right.$; Merck, India) solution (w/v). They were grown hydroponically (Hoaglands solution) [17] with various concentrations of sodium arsenate with or without phosphate and was exposed to $16 \mathrm{~h}$ photoperiod for eighteen days. The seedlings were harvested after a total of 21 days for the following studies.

\subsection{Morphological Studies}

The root and shoot lengths of arsenate treated and untreated seedlings were measured from 21 days old seedlings of both the cultivars. Following this, the separated shoot and root samples were washed, weighed and stored in $-40^{\circ} \mathrm{C}$ for further biochemical assays.

\subsection{Preparation of Supernatant for Assay of Organic Acids Content}

Extraction of pyruvic acid, citric acid and malic acid were performed in a similar manner. $1 \mathrm{~g}$ of shoot and root samples from each of the treatments were homogenised in $5 \mathrm{ml}$ of $0.2 \mathrm{M}$ phosphate buffer ( $\mathrm{pH} 7.4$ ) and centrifuged for $15 \mathrm{mi}-$ nutes at $10,000 \mathrm{rpm}\left(4^{\circ} \mathrm{C}\right)$. The supernatant was then collected, deproteinized using 5\% trichloroacetic acid and filtered. The filtrate was used for the assay of the following organic acid contents.

\subsection{Determination of Pyruvic Acid}

Pyruvic acid estimation was done according to [18]. The reaction mixture comprised of $1.0 \mathrm{ml}$ deproteinized supernatant, $2.0 \mathrm{ml}$ of $0.2 \mathrm{M}$ phosphate buffer, 0.5 $\mathrm{ml}$ of $0.02 \% \mathrm{DNPH}$ (2,4-dinitrophenylhydrazine). The mixture was incubated for 30 minutes at $37^{\circ} \mathrm{C}$ then $5.0 \mathrm{ml}$ of $0.8 \mathrm{~N} \mathrm{NaOH}$ was added followed by another incubation of 10 minutess at room temperature. The mixture without 
plant sample was used as blank. The brown coloured product obtained was measured spectrophotometrically at $510 \mathrm{~nm}$. Amount of pyruvic acid present in the samples was calculated from a standard graph using Sodium pyruvate. The quantity of the total pyruvic acid was expressed as $\mathrm{mg} \cdot \mathrm{g}^{-1} \mathrm{fw}$.

\subsection{Determination of Citric Acid}

Citric acid was determined following the method as described by [19]. The assay mixture contained $1 \mathrm{ml}$ filtrate, $5 \mathrm{ml}$ of analytical grade acetic anhydride and 1.3 $\mathrm{ml}$ of analytical grade pyridine. The mixture was kept in a water bath for $30 \mathrm{~min}$ at $32^{\circ} \mathrm{C} \pm 0.5^{\circ} \mathrm{C}$. The blank contained $1.0 \mathrm{ml}$ distilled water instead of the sample. The optical density (OD) was measured at $405 \mathrm{~nm}$ in a Hitachi U-2000 spectrophotometer. A standard curve was prepared using known concentrations of citric acid. The quantity of the total citric acid was expressed as $\mathrm{mg} \cdot \mathrm{g}^{-1} \mathrm{fw}$.

\subsection{Determination of Malic Acid}

Malic acid estimation was done according to [20]. The reaction mixture contained $0.5 \mathrm{ml}$ of filtrate, $1.0 \mathrm{ml}$ of $1 \mathrm{~N} \mathrm{HCl}, 0.1 \mathrm{ml}$ of $0.1 \% \mathrm{DNPH}$ and $0.5 \mathrm{ml}$ of $10 \% \mathrm{CaCl}_{2}$. The reaction mixture was incubated at room temperature for 30 minutes, followed by addition of $0.3 \mathrm{ml}$ of $5 \mathrm{~N} \mathrm{NH}_{4} \mathrm{OH}$ and $6 \mathrm{ml}$ of absolute alcohol. Tubes were kept undisturbed at room temperature for $12 \mathrm{~h}$ to complete precipitation. After recentrifugation at $5000 \mathrm{rpm}$ for $15 \mathrm{~min}$, the supernatant was poured off. The tubes were dried in an oven at $105^{\circ} \mathrm{C}$ for 15 minutes to remove the moisture. To the dried pellets, $3.0 \mathrm{ml}$ of $0.08 \%$ orcinol esulphuric acid mixture was added, the contents were mixed thoroughly with a glass rod and the tubes were heated to $100^{\circ} \mathrm{C}$ for $10 \mathrm{~min}$. The mixtures were cooled under the tap water and diluted to $10 \mathrm{ml}$ with concentrated $\mathrm{H}_{2} \mathrm{SO}_{4}$. The blue fluorescence produced was measured using a Hitachi-650-40 spectrofluorometer against blank. The amount of total malic acid was expressed as mg. $\mathrm{g}^{-1} \mathrm{fw}$.

\section{Determination of Activities TCA Cycle Enzymes}

\subsection{Assay of Pyruvate Dehydrogenase}

Pyruvate dehydrogenase (E.C. 1.2.4.1) assay was done following the method of [21]. The plant samples were homogenised in $1.5 \mathrm{ml}$ of $50 \mathrm{mM}$ Tris $\mathrm{HCl}$ buffer (pH 7.8) containing $0.7 \mathrm{M}$ sucrose, $57 \mathrm{mM} \beta$-mercaptoethanol, $2 \mathrm{mM}$ EDTA and $0.5 \%(\mathrm{w} / \mathrm{v}) \mathrm{BSA}$ and centrifuged at $10,000 \mathrm{rpm}$ for $20 \mathrm{~min}$ at $4^{\circ} \mathrm{C}$. A The assay mixture contained $0.2 \mathrm{ml}$ of the supernatant, $0.2 \mathrm{ml}$ of $50 \mathrm{mMTris} \mathrm{HCl}(\mathrm{pH} 8.0$ ) and $0.1 \mathrm{ml}$ each of $5 \mathrm{mMMgCl}_{2}, 0.12 \mathrm{mM} \mathrm{CoA}, 2.6 \mathrm{mM}$ cysteine $\mathrm{HCl}$ and 1.5 $\mathrm{mM}$ pyruvate making a total volume $1.0 \mathrm{ml}$. The $\mathrm{OD}$ of reaction mixture was measured in a Hitachi U-2000 spectrophotometer with respect to a blank at 340 $\mathrm{nm}$. Then $0.2 \mathrm{ml}$ of $1.4 \mathrm{mM}$ NAD was added to the reaction mixture, mixed well and the absorption was further noted for every $60 \mathrm{~s}$ for $2 \mathrm{~min}$. An increasing OD showed the amount of NADH produced per minute. A standard curve with known concentrations of NADH was prepared from which the PDC activity was calculated and expressed as $\mathrm{mmol} \mathrm{NADH}$ formed $\mathrm{min}^{-1} \cdot \mathrm{mg}^{-1}$ protein. 


\subsection{Assay of Citrate Synthase}

Citrate synthase (EC 2.3.3.1) activity was determined according to the method described by [22]. Samples were homogenised in a buffer containing $0.1 \mathrm{~mol} / \mathrm{L}$ Tris-HCl buffer ( $\mathrm{pH}$ 8.0), 0.1\% (v/v) Triton X-100 (Triton -100), 2\% (w/v) PVP (Polyvinyl polypyrrolidone), and $10 \mathrm{mmol} / \mathrm{L}$ iso-ascorbic acid. The extracts were centrifuged for $5 \mathrm{~min}$ at $15,000 \mathrm{rpm}$ at $4^{\circ} \mathrm{C}$ and the supernatant was assayed for enzyme activity. The reaction mixture comprised of $0.1 \mathrm{ml} 1 \mathrm{mM}$ DTNB (5'-Dithiobis-2-Nitrobenzoic Acid), $0.03 \mathrm{ml}$ of $10 \mathrm{mM}$ acetyl CoA and $0.05 \mathrm{ml}$ supernatant. Initial absorbance was recorded followed by addition of $0.05 \mathrm{ml} 10 \mathrm{mM}$ OAA(oxalo acetate) and final absorbance was recorded at $412 \mathrm{~nm}$ in a Hitachi U-2000 spectrophotometer. Enzyme activity was calculated as $\mu$ mol citric acid decomposed $\mathrm{mg}^{-1}$ protein $\mathrm{min}^{-1}$.

\subsection{Assay of Isocitrate Dehydrogenase}

Isocitrate dehydrogenase (E.C. 1.1.1.41) activity was determined following the method of [23]. Root and shoot samples were homgenized in $1.5 \mathrm{ml}$ of $50 \mathrm{mM}$ Hepes buffer ( $\mathrm{pH}$ 7.5) containing $10 \mathrm{mM} \beta$-mercaptoethanol and 5\% polyvinylpolypyrrolidone. The homogenates were centrifuged at 14,500 g for $20 \mathrm{~min}$ at $4^{\circ} \mathrm{C}$. The assay mixture contained $40 \mathrm{mM}$ Hepes buffer ( $\mathrm{pH} 8.2$ ), $2 \mathrm{mM}$ sodium isocitrate, $800 \mathrm{mM} \mathrm{NAD}, 200 \mathrm{mM} \mathrm{MnSO}_{4}$ and $0.1 \mathrm{ml}$ enzyme making a final volume of $0.5 \mathrm{ml}$. The increase in absorbance of the reaction mixture was measured in a Hitachi U-2000 spectrophotometer at $340 \mathrm{~nm}$ for $2 \mathrm{~min}$. The enzyme activity was expressed as $\mathrm{mmol} \mathrm{NADH}$ formed $\mathrm{min}^{-1} \cdot \mathrm{mg}^{-1}$ protein.

\subsection{Assay of Succinate Dehydrogenase}

Succinate dehydrogenase (E.C. 1.3.5.1) activity was determined according to [24]. Root and shoot samples were homgenized in $1.5 \mathrm{ml}$ of $4 \mathrm{mMTris} \mathrm{HCl}$ ( $\mathrm{pH}$ 7.5) buffer containing $0.19 \mathrm{M}$ sucrose. The homogenates were centrifuged at $10,000 \mathrm{rpm}$ for $15 \mathrm{~min}$ at $4^{\circ} \mathrm{C}$. The assay mixture contained $0.1 \mathrm{ml}$ of distilled water, $0.05 \mathrm{ml}$ each of $0.19 \mathrm{M}$ sucrose, $0.1 \mathrm{MTris} \mathrm{HCl}(\mathrm{pH} 7.5), 10 \mathrm{mM}$ sodium azide, $8 \mathrm{mM}$ INT [2-(p-iodophenyl)-3-(pnitrophenyl)-5-(phenyl tetrazolium chloride)], $0.1 \mathrm{ml}$ of $0.5 \mathrm{M}$ sodium succinate and $0.1 \mathrm{ml}$ supernatant. The mixture was incubated at $30^{\circ} \mathrm{C}$ in a water bath for $10 \mathrm{~min} .95 \%$ alcohol was added to each tube, mixed thoroughly and kept in an ice bath for $10-15 \mathrm{~min}$. Finally, the mixtures were centrifuged at $8000 \mathrm{rpm}$ at room temperature for $10 \mathrm{~min}$ and absorbance was recorded at $458 \mathrm{~nm}$. Basal reduction of INT was determined in control tubes without succinate. The enzyme activity was expressed as mmol INT reduced $\mathrm{min}^{-1} \cdot \mathrm{mg}^{-1}$ protein.

\subsection{Assay of Fumarase}

Fumarse (E.C. 4.2.1.2.) activity was estimated according to [25]. Plant samples were ground in liquid nitrogen and extracted in a buffer comprising of $10 \%(\mathrm{v} / \mathrm{v})$ glycerol. 0.25\%(w/v) BSA, 0.1\%(v/v) TritonX -100, 50 mM HEPES/KOH pH7.5,

$10 \mathrm{mM} \mathrm{MgCl}_{2}, 1 \mathrm{mM}$ EDTA, $1 \mathrm{mM}$ EGTA, $1 \mathrm{mM}$ benzamidine, $1 \mathrm{mM} \varepsilon$ amino 
caprionic acid, $1 \mathrm{mM}$ phenyl methyl sulphonyl fluoride, $10 \mu \mathrm{M}$ leupeptin and $1 \mathrm{mM}$ DTT. The assay mixture comprised of $100 \mathrm{mM}$ Tricine /KOH pH 8.0, 0.2 $\mathrm{mM}$ acetyl CoA, $5 \mathrm{mM}$ phosphate, $5 \mathrm{mM} \mathrm{MgCl}_{2}, 0.15 \mathrm{mM} \mathrm{NAD+}, 0.5(\mathrm{v} / \mathrm{v})$ TritonX $-100,50$ units malate dehydrogenase and 1 unit $\mathrm{ml}^{-1}$ citrate synthase. The reaction was started by addition of fumarate and was terminated with $20 \mu \mathrm{l} 0.5$ $\mathrm{NaOH}$. The increase in absorbance was measured at $380 \mathrm{~nm}$ at 10 seconds for at least 60 seconds.

\subsection{Assay of Malate Dehydrogenase}

Malate dehydrogenase (E.C. 1.1.1.37) activity was determined according to [26]. $1 \mathrm{~g}$ plant sample from each set was homogenized in $3 \mathrm{ml}$ of $50 \mathrm{mMTris} \mathrm{HCl}(\mathrm{pH}$ 8.0) buffer containing $50 \mathrm{mM} \mathrm{MgCl}, 5 \mathrm{mM} \beta$-mercaptoethanol and $1 \mathrm{mM}$ EDTA and centrifuged at $10,000 \mathrm{rpm}$ for $20 \mathrm{~min}$ at $4^{\circ} \mathrm{C}$. The assay mixture was prepared with $0.5 \mathrm{ml}$ of $5 \mathrm{mM}$ OAA, $0.5 \mathrm{ml}$ of $10 \mathrm{mM} \mathrm{MgCl}_{2}, 1.3 \mathrm{ml}$ of $0.1 \mathrm{M}$ Tris $\mathrm{HCl}$ buffer ( $\mathrm{pH} 7.8$ ) and $0.2 \mathrm{ml}$ of the enzyme extract. The initial absorbance of the reaction mixture was measured in a Hitachi U-2000 spectrophotometer at $340 \mathrm{~nm}$. Then $0.5 \mathrm{ml}$ of $0.4 \mathrm{mM} \mathrm{NADH}$ was added and absorption was recorded every $60 \mathrm{~s}$ for at least $2 \mathrm{~min}$. The enzyme activity was expressed as mmol NADH oxidized $\mathrm{min}^{-1} \cdot \mathrm{mg}^{-1}$ protein.

\subsection{Protein Estimation}

Protein contents were estimated according to [27], using bovine serum albumin (BSA, Sigma) as standard.

\subsection{Statistical Analysis}

The experiments were carried out in a completely randomized design (CRD) with 3 replicates; each replication comprised a single petridish containing an average of 70 - 80 seeds. The data and significant differences among mean values were compared by descriptive statistics $( \pm \mathrm{SE})$ followed by Student's $t$ test. The values of $P \leq 0.05$ were considered as statistically significant.

\section{Results}

\subsection{Effect of Arsenate on Growth of 21 Days Old Rice Seedlings}

The normal growth of the shoot as well as the root was affected by arsenic toxicity. The shoot and root lengths decreased linearly with increasing concentrations of arsenate in both the test cultivars (Table 1), however the reduction in growth was more significant in cv. IR64 than in cv. Nayanmani. In cv. IR64 the reduction in shoot length was $8 \%, 17 \%$ and $51 \%$, while in cv. Nayanmani shoots the decrease was $13 \%, 20 \%$ and $29 \%$. The inhibition in root lengths was $12 \%, 33 \%$, $52 \%$ in cv. IR64 and 9\%, 21\%,33\% in cv. Nayanmani. On co-application of phosphate along with arsenate, there was considerable revival in growth with cv. IR64 showing 9\% and 16\% average reduction in shoot and root lengths. In comparison, cv. Nayanmani experienced $7 \%$ and $14 \%$ inhibition in shoot and root lengths on an average (Figure 1 and Figure 2). 


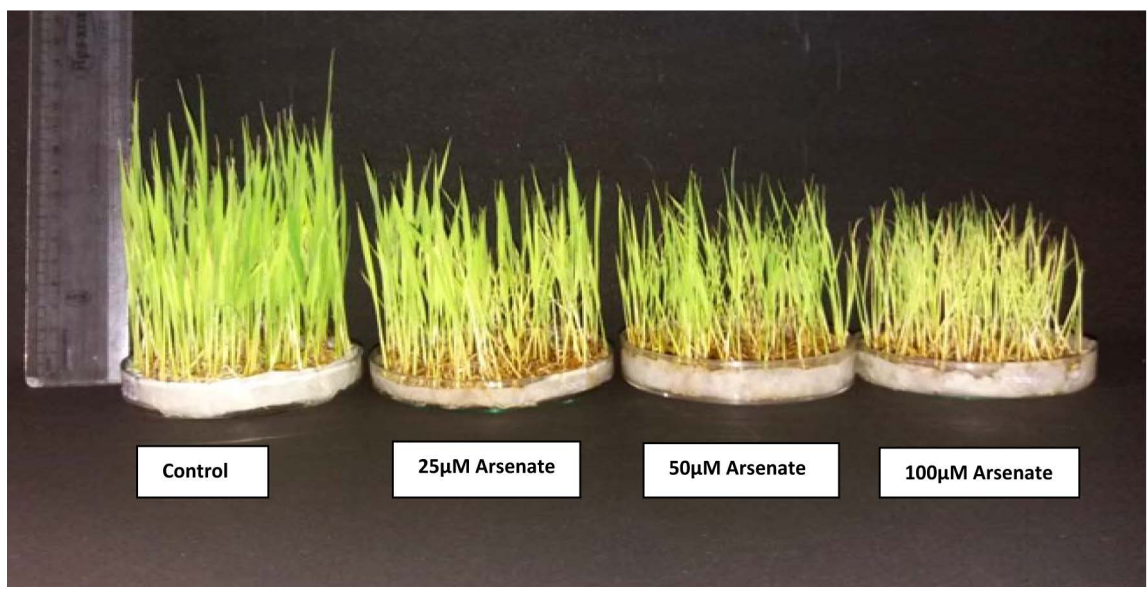

(a)

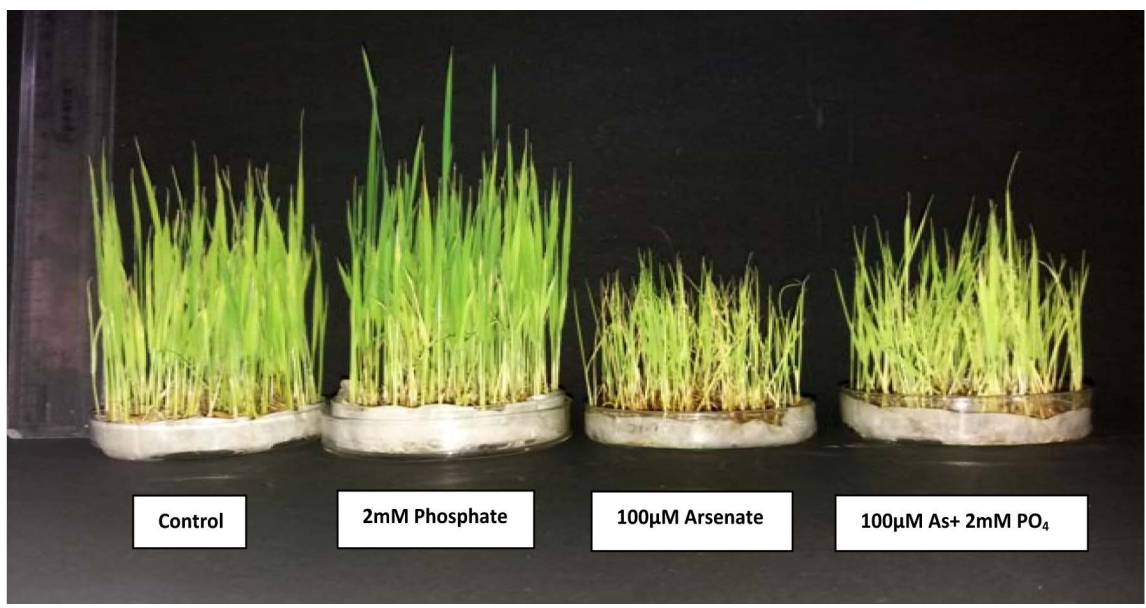

(b)

Figure 1. (a) (b) Effect of arsenate and phosphate applied singly or in combination on the growth of 21 days old rice (cv. IR64) seedlings.

Table 1. Table showing shoot and root lengths of 21 days old rice seedlings.

\begin{tabular}{ccccc}
\hline \multirow{2}{*}{ Treatment } & \multicolumn{2}{c}{$\begin{array}{c}\text { cv. IR64 } \\
\text { (length } \text { in cm) }\end{array}$} & \multicolumn{2}{c}{$\begin{array}{c}\text { cv. Nayanmani } \\
\text { (length in cm) }\end{array}$} \\
\cline { 2 - 5 } & Shoot & Root & Shoot & Root \\
\hline $\begin{array}{c}\text { Control } \\
\text { Arsenate }(\mu \mathrm{M})\end{array}$ & $6.95 \pm 0.75$ & $10.8 \pm 1.22$ & $7.17 \pm 0.93$ & $9.57 \pm 1.39$ \\
25 & $6.42 \pm 1.05$ & $9.53 \pm 0.45$ & $6.23 \pm 0.69$ & $8.67 \pm 0.98$ \\
50 & $5.77 \pm 0.48^{*}$ & $7.19 \pm 0.63^{*}$ & $5.77 \pm 0.52$ & $7.57 \pm 0.75$ \\
100 & $3.38 \pm 0.62^{*}$ & $5.15 \pm 0.32^{*}$ & $5.10 \pm 0.34^{*}$ & $6.37 \pm 0.51^{*}$ \\
Phosphate $(2 \mathrm{mM})$ & $7.60 \pm 0.88$ & $11.0 \pm 0.52$ & $7.73 \pm 0.81$ & $10.2 \pm 0.87$ \\
+ Arsenate & & & & \\
25 & $7.27 \pm 0.97$ & $10.2 \pm 1.24$ & $7.10 \pm 0.46$ & $9.27 \pm 0.98$ \\
50 & $6.57 \pm 0.23^{*}$ & $9.38 \pm 0.89$ & $6.73 \pm 0.64$ & $8.43 \pm 0.34$ \\
100 & $5.73 \pm 1.11$ & $7.57 \pm 0.5^{*}$ & $6.17 \pm 0.23^{*}$ & $6.90 \pm 0.29^{*}$ \\
\hline
\end{tabular}




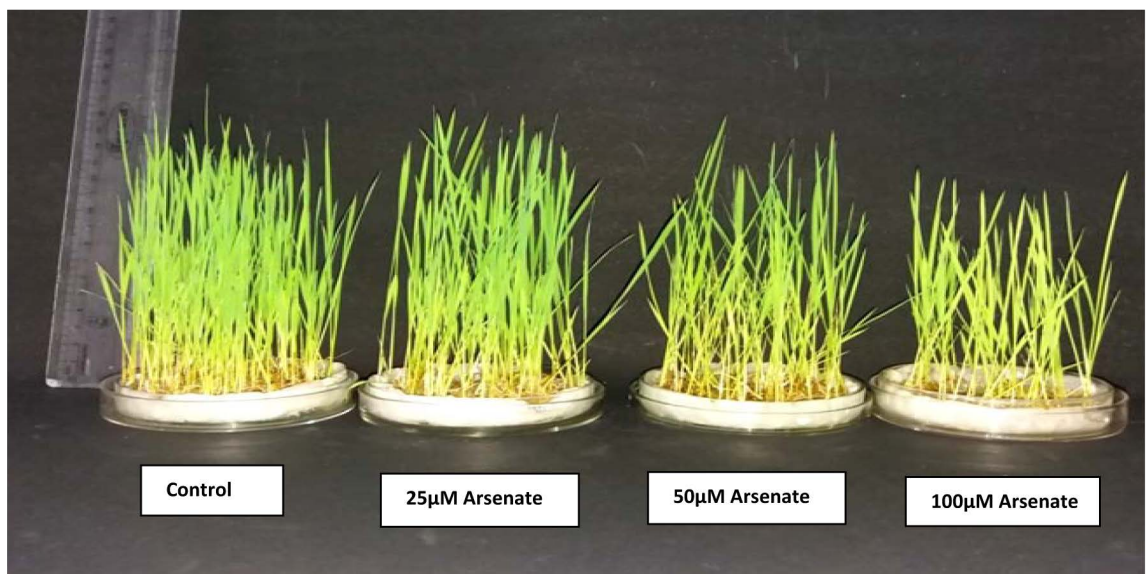

(a)

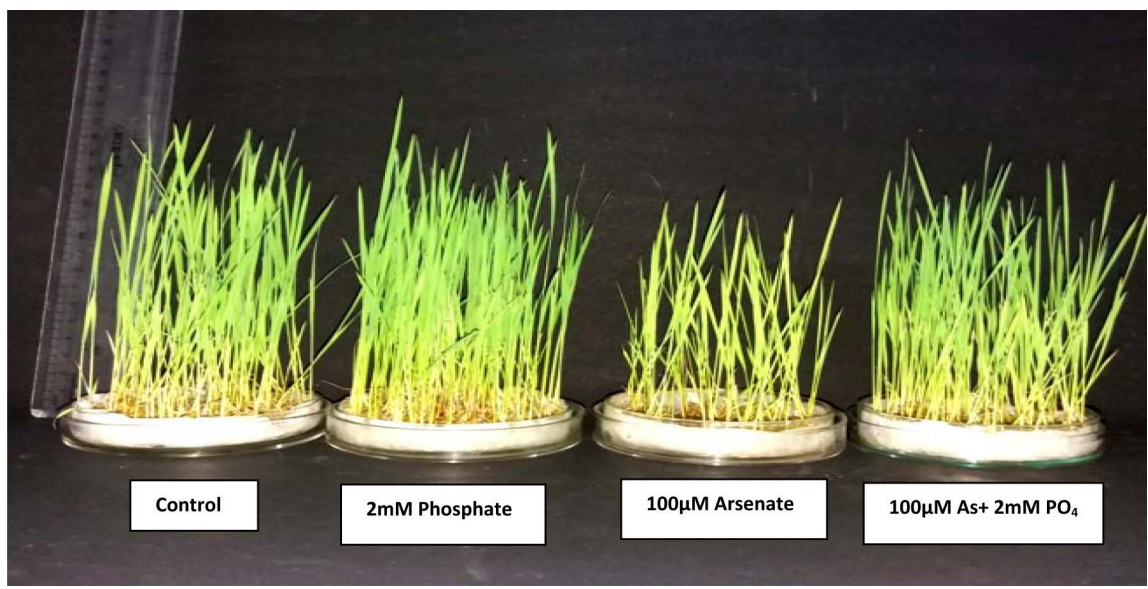

(b)

Figure 2. (a) (b) Effect of arsenate and phosphate applied singly or in combination on the growth of 21 days old rice (cv. Nayanmani) seedlings.

\subsection{Effect of Arsenate on the Intermediates of Krebs' Cycle}

The organic acids namely pyruvate, citrate and malate were measured in both the root and the shoot samples of 21 days old rice seedlings of cultivars IR64 and Nayanmani under various concentrations of arsenate (As) treatment. The levels of organic acids were generally higher in the roots than the shoots in both the cultivars under As stress with cv. IR64 (Table 2) experiencing more elevation in comparison to cv. Nayanamani (Table 3).

Root and shoot of cv. IR64 showed 51\% and 45\% increment in pyruvate levels respectively while cv. Nayanmani experienced $36 \%$ and $22 \%$ elevation in pyruvic acid contents in its root and shoot on an average respectively under increasing arsenic treatment. Citrate levels also escalated under various concentrations of As stress with cv. IR64 elevation of showing 36\%,77\%, 103\% in root and 24\%, $67 \%, 114 \%$ in shoot under $25 \mu \mathrm{M}, 500 \mu \mathrm{M}$ and $100 \mu \mathrm{M}$ As treatments respectively. Cv. Nayanmani in comparison underwent 51\%, 89\%, 101\% and 19\%, 67\% and $85 \%$ elevation in citric acid contents in the root and shoot respectively. Malic acid content in cv. IR64 showed $97 \%$ and $212 \%$ increment on an average in the root and shoot respectively by arsenic treatment, while cv. Nayanmani 
Table 2. Table showing the levels of organic acids content in 21 days old cv. IR64 seedling.

\begin{tabular}{|c|c|c|c|c|c|c|}
\hline \multirow{2}{*}{ Treatment } & \multicolumn{2}{|c|}{$\begin{array}{l}\text { Pyruvic acid content } \\
(\mathrm{mg} / \mathrm{g} \mathrm{fw})\end{array}$} & \multicolumn{2}{|c|}{$\begin{array}{l}\text { Citric acid content } \\
(\mathrm{mg} / \mathrm{g} \mathrm{fw})\end{array}$} & \multicolumn{2}{|c|}{$\begin{array}{l}\text { Malic acid content } \\
(\mathrm{mg} / \mathrm{g} \mathrm{fw})\end{array}$} \\
\hline & Shoot & Root & Shoot & Root & Shoot & Root \\
\hline Control & $3.2 \pm 0.15$ & $3.5 \pm 0.25$ & $0.58 \pm 0.09$ & $2.15 \pm 0.34$ & $1.29 \pm 0.09$ & $2.10 \pm 0.02$ \\
\hline \multicolumn{7}{|l|}{ Arsenate $(\mu \mathrm{M})$} \\
\hline 25 & $3.9 \pm 0.90$ & $4.0 \pm 0.18$ & $0.72 \pm 0.02$ & $2.93 \pm 0.21$ & $3.62 \pm 0.15^{\star}$ & $3.65 \pm 0.40^{*}$ \\
\hline 50 & $4.3 \pm 0.05^{\star}$ & $5.5 \pm 0.70$ & $0.97 \pm 0.14$ & $3.81 \pm 0.15^{\star}$ & $4.15 \pm 0.52^{\star}$ & $4.18 \pm 0.01^{\star}$ \\
\hline 100 & $5.7 \pm 0.68^{*}$ & $6.4 \pm 0.85^{\star}$ & $1.24 \pm 0.22^{*}$ & $4.36 \pm 0.58^{*}$ & $4.32 \pm 0.27^{\star}$ & $4.59 \pm 0.39^{*}$ \\
\hline Phosphate (2mM) & $3.0 \pm 0.28$ & $3.4 \pm 0.16$ & $0.45 \pm 0.03$ & $2.02 \pm 0.29$ & $1.30 \pm 0.16$ & $2.02 \pm 0.13$ \\
\hline \multicolumn{7}{|l|}{ +Arsenate } \\
\hline 25 & $3.3 \pm 0.53$ & $4.0 \pm 0.40$ & $0.55 \pm 0.07$ & $2.09 \pm 0.16$ & $1.87 \pm 0.31$ & $2.53 \pm 0.19$ \\
\hline 50 & $3.5 \pm 0.45$ & $4.3 \pm 0.29$ & $0.61 \pm 0.10$ & $2.51 \pm 0.24$ & $2.74 \pm 0.12^{\star}$ & $3.35 \pm 0.07^{*}$ \\
\hline 100 & $4.6 \pm 0.27^{\star}$ & $5.9 \pm 0.50^{*}$ & $0.89 \pm 0.09$ & $3.17 \pm 0.41$ & $3.06 \pm 0.05^{*}$ & $3.99 \pm 0.56^{*}$ \\
\hline
\end{tabular}

Table 3. Table showing the levels of organic acids content in 21 days old cv. Nayanmani seedlings.

\begin{tabular}{|c|c|c|c|c|c|c|}
\hline \multirow{2}{*}{ Treatment } & \multicolumn{2}{|c|}{$\begin{array}{l}\text { Pyruvic acid content } \\
(\mathrm{mg} / \mathrm{g} \mathrm{fw})\end{array}$} & \multicolumn{2}{|c|}{$\begin{array}{l}\text { Citric acid content } \\
(\mathrm{mg} / \mathrm{g} \mathrm{fw})\end{array}$} & \multicolumn{2}{|c|}{$\begin{array}{l}\text { Malic acid content } \\
(\mathrm{mg} / \mathrm{g} \mathrm{fw})\end{array}$} \\
\hline & Shoot & Root & Shoot & Root & Shoot & Root \\
\hline Control & $2.8 \pm 0.49$ & $2.8 \pm 0.21$ & $1.60 \pm 0.12$ & $1.09 \pm 0.21$ & $4.61 \pm 0.06$ & $3.78 \pm 0.03$ \\
\hline \multicolumn{7}{|l|}{ Arsenate $(\mu \mathrm{M})$} \\
\hline 25 & $2.8 \pm 0.52$ & $3.4 \pm 0.17$ & $2.19 \pm 0.17^{\star}$ & $1.65 \pm 0.28$ & $5.75 \pm 0.22^{*}$ & $4.92 \pm 0.66$ \\
\hline 50 & $3.4 \pm 0.45$ & $3.8 \pm 0.10$ & $2.68 \pm 0.20^{*}$ & $2.06 \pm 0.22^{*}$ & $6.15 \pm 0.75$ & $5.65 \pm 0.14^{*}$ \\
\hline 100 & $4.1 \pm 0.31$ & $4.2 \pm 0.09^{*}$ & $2.96 \pm 0.28^{\star}$ & $2.20 \pm 0.16^{\star}$ & $6.09 \pm 0.39^{*}$ & $5.81 \pm 0.49^{*}$ \\
\hline Phosphate (2mM) & $2.6 \pm 0.35$ & $3 . .4 \pm 0.22$ & $1.08 \pm 0.40$ & $1.08 \pm 0.05$ & $4.22 \pm 0.17$ & $3.53 \pm 0.07^{\star}$ \\
\hline \multicolumn{7}{|l|}{+ Arsenate } \\
\hline 25 & $2.8 \pm 0.43$ & $2.8 \pm 0.07$ & $1.73 \pm 0.37$ & $1.08 \pm 0.21$ & $4.50 \pm 0.29$ & $3.21 \pm 0.33$ \\
\hline 50 & $3.2 \pm 0.26$ & $3.5 \pm 0.23$ & $1.80 \pm 0.32$ & $1.10 \pm 0.26$ & $5.31 \pm 0.11^{\star}$ & $4.95 \pm 0.41^{\star}$ \\
\hline 100 & $3.8 \pm 0.18$ & $4.2 \pm 0.12^{*}$ & $1.88 \pm 0.28$ & $1.64 \pm 0.14$ & $5.39 \pm 0.59$ & $5.50 \pm 0.58^{*}$ \\
\hline
\end{tabular}

showed comparatively less increase of about $44 \%$ and $30 \%$ on an average in the root and shoot respectively.

Application of $2 \mathrm{mM}$ phosphate along with arsenate in all the cases showed alleviation of arsenic toxicity to different levels resulting in reduced secretion of the organic acids. Pyruvate, citrate and malate contents under joint treatment of arsenate and phosphate showed 17\%, 13\%, 17\% average elevation in Nayanmani shoot and 25\%,17\%, 21\% average increase in Nayanmani root respectively. In comparison cv. IR64 shoot experienced 18\%, 18\%, 98\% average increase in pyruvate, citrate and malate contents, while cv. IR64 roots showed 35\%, 21\% and $57 \%$ average increase in the concentrations of the above mentioned organic ac- 
ids with respect to arsenic treatment alone.

\subsection{Effect on the Activities of Krebs Cycle Enzymes}

\subsubsection{Pyruvate Dehydrogenase Activity}

Activity of pyruvate dehydrogenase (PDH) enzyme declined in both the cultivars to varying extent on treatment with increasing doses of sodium arsenate. In $\mathrm{cv}$. Nayanmani, the reduction in PDH activity was about $49 \%$ in root followed by $23 \%$ reduction in the shoot of the same on an average. The cv. IR64 experienced around 50\% and 39\% decrease in PDH activity in the root and shoot respectively under As stress. On application of phosphate along with arsenate PDH activity revived to some extent in both the cultivars with cv. Nayanmani showing $12 \%$ decline each in the root and shoot, while cv. IR64 experienced 23\% and 22\% average reduction in the root and the shoot respectively (Figure 3 ).

\subsubsection{Citrate Synthase Activity}

Roots of cv. IR64 exhibited 23\%, $89 \%$ and $112 \%$ elevation in citrate synthase (CS) activity while the shoots recorded an increment of $45 \%, 61 \%$ and $118 \%$ over water control under $25 \mu \mathrm{M}, 50 \mu \mathrm{M}$ and $100 \mu \mathrm{M}$ As treatment respectively. In cv. Nayanmani root the reduction in enzyme activity was 15\%, 20\% and 58\% while in shoot the average increase in CS activity was $29 \%$ over control under same concentrations of arsenate treatment. Co-application of phosphate along with arsenate showed significant reduction in the activity of CS enzyme with $\mathrm{cv}$. IR64 recording $23 \%$ and $25 \%$ average elevation in the root and shoot respectively, while the test seedlings cv. Nayanmani showed just $8 \%$ and $1 \%$ average increase in the root and shoot respectively (Figure 4).

\subsubsection{Isocitrate Dehydrogenase Activity}

The shoot and root of cv. IR64 experienced 21\%, 53\%, 57\% and 26\%, 45\%, 47\%

Pyruvate Dehydrogenase Activity in cv.IR64

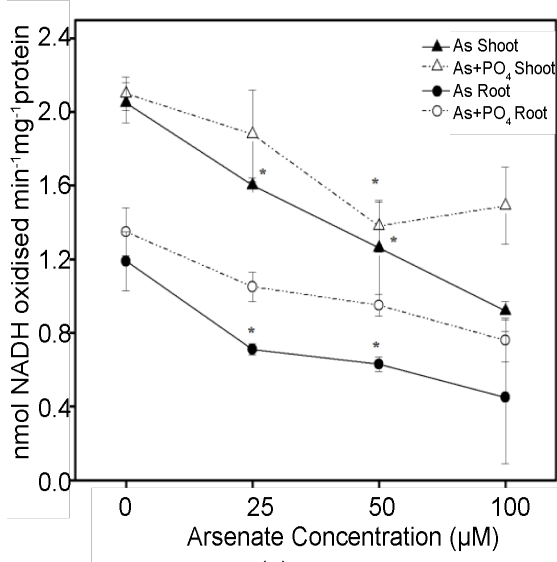

(a)
Pyruvate Dehydrogenase Activity in cv.Nayanmani

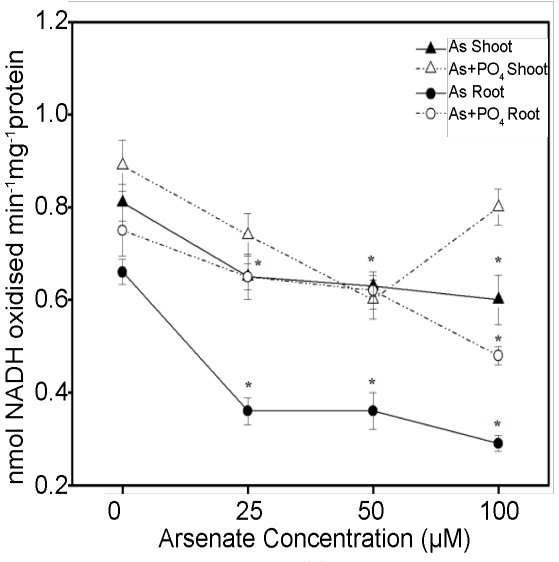

(b)

Figure 3. (a) (b) Effect of Arsenate and phosphate applied singly or in combination on the Pyruvate Dehydrogenase (PDH) Activity of 21 days old rice seedlings. The values are means of 3 replicas \pm SE. ${ }^{*}$ indicates statistically significant at $P \leq 0.05$ respectively as compared to water control. 


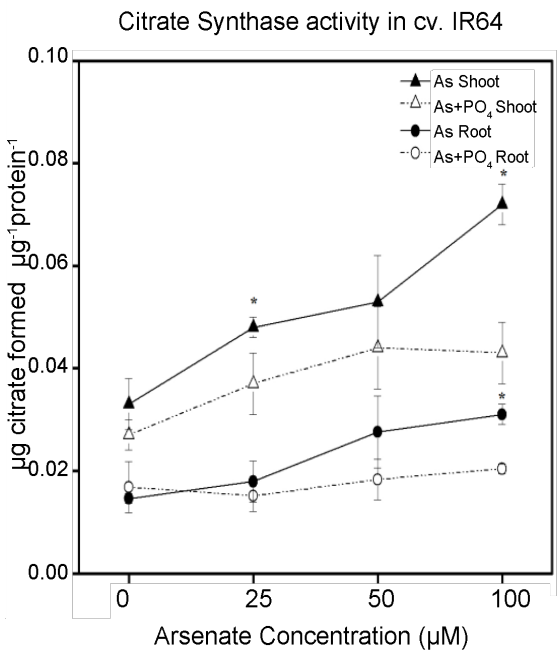

(a)

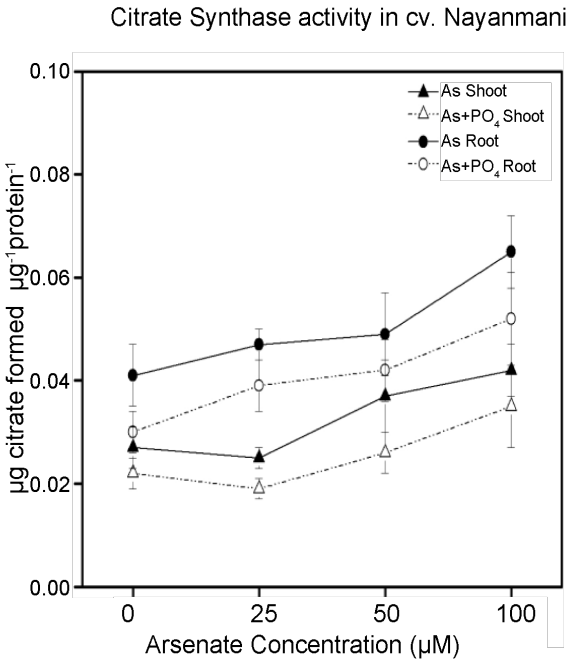

(b)

Figure 4. (a) (b) Effect of arsenate and phosphate applied singly or in combination on the citrate synthase (CS) activity of 21 days old rice seedlings. The values are means of 3 replicas \pm SE. ${ }^{*}$ indicates statistically significant at $P \leq 0.05$ respectively as compared to water control.

decline in isocitrate dehydrogenase (IDH) activity respectively under $25 \mu \mathrm{M}, 50$ $\mu \mathrm{M}$ and $100 \mu \mathrm{M}$ treatments of sodium arsenate with respect to water control. Addition of $2 \mathrm{mM}$ phosphate along with arsenate resulted in some revival of the enzyme activity in cv. IR64 with the shoot showing average 13\% reduction and the root $19 \%$ in comparison to water control. Cv. Nayanmani in comparison exhibited less inhibition of IDH activity where the root and shoot displayed $21 \%$ and $14 \%$ average reduction respectively on arsenate treatment alone, while coapplication of phosphate resulted in improved enzyme activity in both the root (10\% inhibition) and the shoot (9\% inhibition) in comparison to water control (Figure 5).

\subsubsection{Succinate Dehydrogenase Activity}

The enzymatic activity of succinate dehydrogenase (SDH) in cv. IR64 root and shoot reduced by about $42 \%$ and $43 \%$ on an average, respectively with respect to water control. In cv. Nayanmani the decline in SDH activity was less significant amounting to $13 \%$ and $9 \%$ in average in the shoot and root respectively on arsenate treatment alone. Addition of phosphate along with arsenate exhibited less reduction in SDH activity in both the cultivars compared to arsenate treatment alone. In cv. IR64 shoot and root, the decline was $15 \%$ and $12 \%$, while in $\mathrm{cv}$. Nayanmani it was $6 \%$ and $1 \%$ in average respectively (Figure 6).

\subsubsection{Fumarase Activity}

An elevation in fumarase activity was observed under increasing concentrations of arsenic in both the test seedlings with cv. IR64 seedlings showing average $118 \%$ and $69 \%$ increase in the root and shoot respectively. Cv. Nayanmani experienced $57 \%$ and $49 \%$ elevation on an average in the root and shoot with respect 
Isocitrate Dehydrogenase activity in cv. IR64

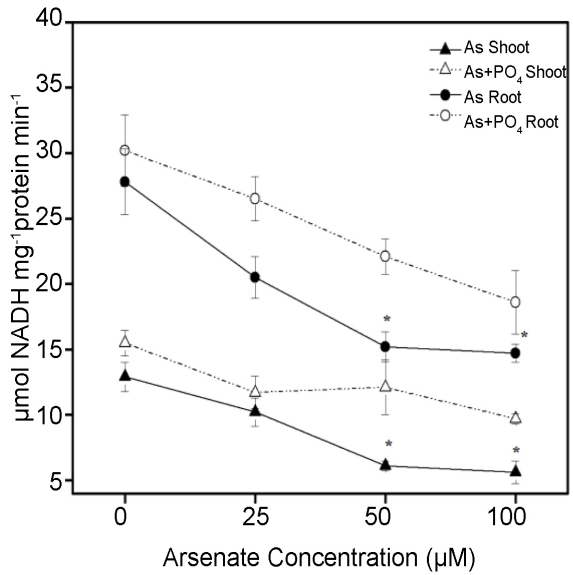

(a)
Isocitrate Dehydrogenase activity in cv. Nayanmani

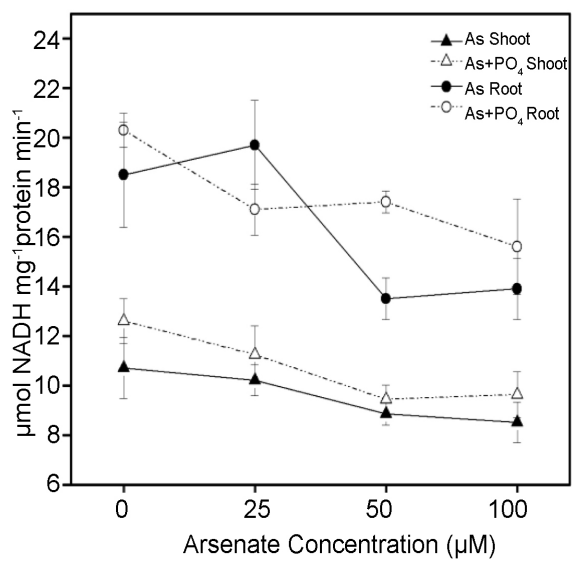

(b)

Figure 5. (a) (b) Effect of arsenate and phosphate applied singly or in combination on the Isocitrate Dehydrogenase (IDH) activity of 21 days old rice seedlings. The values are means of 3 replicas $\pm \mathrm{SE} .{ }^{*}$ indicates statistically significant at $P \leq 0.05$ respectively as compared to water control.

Succinate dehydrogenase in cv. IR64

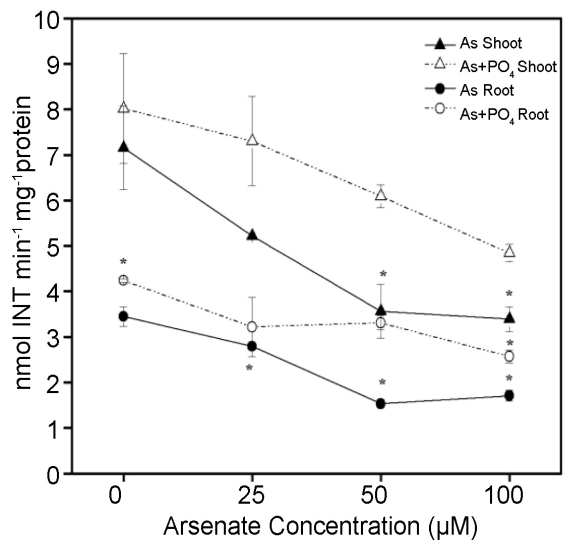

(a)
Succinate dehydrogenase activity in cv. Nayanmani

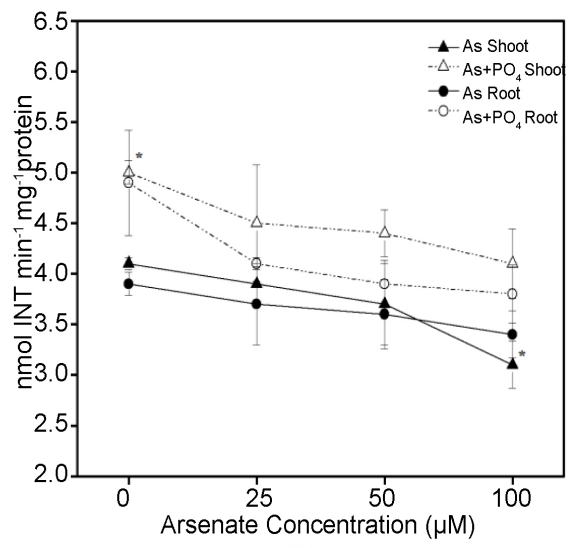

(b)

Figure 6. (a) (b) Effect of arsenate and phosphate applied singly or in combination on the succinate dehydrogenase (SDH) activity of 21 days old rice seedlings. The values are means of 3 replicas $\pm \mathrm{SE}$. ${ }^{*}$ indicates statistically significant at $P \leq 0.05$ respectively as compared to water control.

to water control under As treatment alone. Co-application of phosphate along with arsenate resulted in less escalated fumarase activity in the test cultivars. Cv. Nayanmani showed $31 \%$ and $14 \%$ increase, while cv. IR64 experienced $44 \%$ and $18 \%$ increase on an average in the roots and shoots in comparison to water control (Figure 7).

\subsubsection{Malate Dehydrogenase Activity}

Malate dehydrogenase $(\mathrm{MDH})$ activity was inhibited under As stress. Cv. IR64 experienced $37 \%, 52 \%, 67 \%$ and $21 \%, 28 \%, 42 \%$ reduction in the root and shoot respectively under increasing arsenate treatment. In cv. Nayanmani roots and 


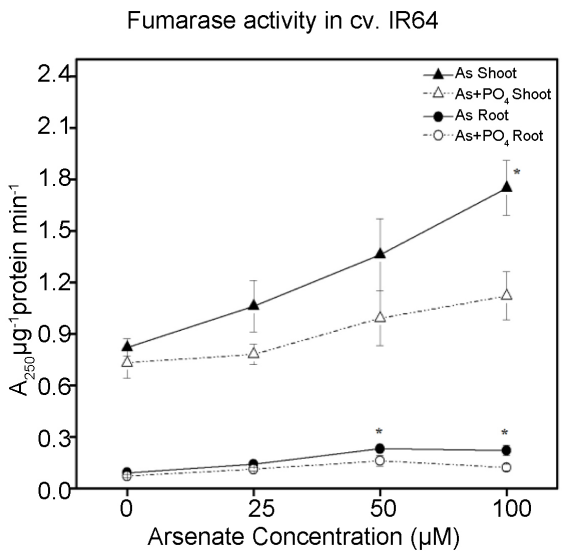

(a)

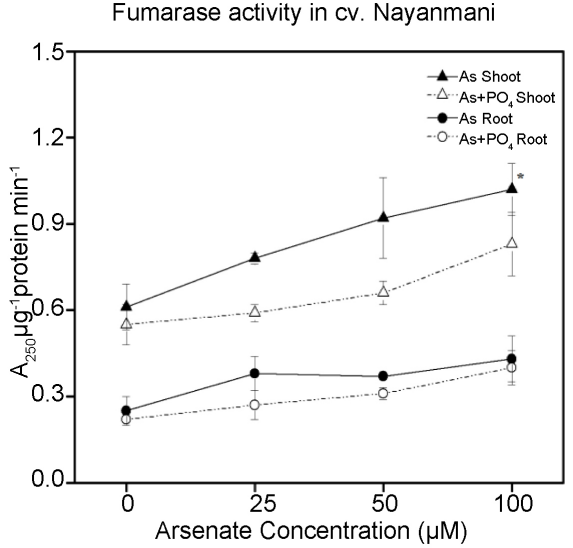

(b)

Figure 7. (a) (b) Effect of arsenate and phosphate applied singly or in combination on the Fumarase activity of 21 days old rice seedlings. The values are means of 3 replicas \pm SE. * indicates statistically significant at $P \leq 0.05$ respectively as compared to water control.

shoots, this inhibition was $14 \%, 33 \%, 38 \%$ and $9 \%, 25 \%, 34 \%$ respectively in comparison to water control. Joint application of phosphate along with arsenate alleviated the toxic effect of arsenic to some extent with cv. Nayanamani root and shoot showing average $13 \%$ and $7 \%$ decrease in enzyme activity, while cv. IR64 recorded 31\% and 25\% inhibition in the root and shoot on an average respectively (Figure 8).

\section{Discussion}

\subsection{Effect on Growth}

Reduction in growth is usually observed in plants exposed to arsenic stress. The root system was much more affected than the shoots, becoming stubby, brittle and turning brown. The inhibition was stronger in roots than in shoots when exposed to arsenic because the roots are the first point of contact, as arsenate is taken up by the phosphate transporters present in the roots [28]. The metalloid also hindered root extension and proliferation. With increasing concentrations of arsenate the shoots became more stunted resulting in decreased biomass. [29] reviewed that translocation of As to the shoot drastically impedes plant growth by retarding development and biomass accumulation resulting in reduced reproductive sufficiency. Similar effect was observed in Holcus lanatus [30], wheat [31] and rice [32]. In our study too, the rice seedlings when exposed to increasing concentrations of arsenate, experienced much more inhibition in root length than in the shoots and this effect was more prominent in cv. IR64 than in $\mathrm{cv}$. Nayanmani which showed partial tolerance to arsenic toxicity.

\subsection{Effect on the Intermediates of Krebs Cycle}

The formation and regulation of organic acids by TCA cycle in plants is a highly intricate phenomenon. Apart from respiration, photosynthesis and nitrogen metabolism, organic acids are said to have vital roles in helping the plant to adapt to nutrient deficiencies and metal stress [33]. We have recorded the pyru 


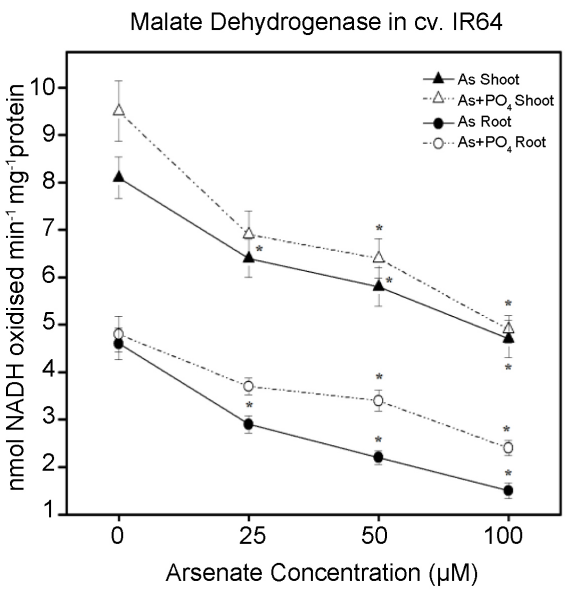

(a)

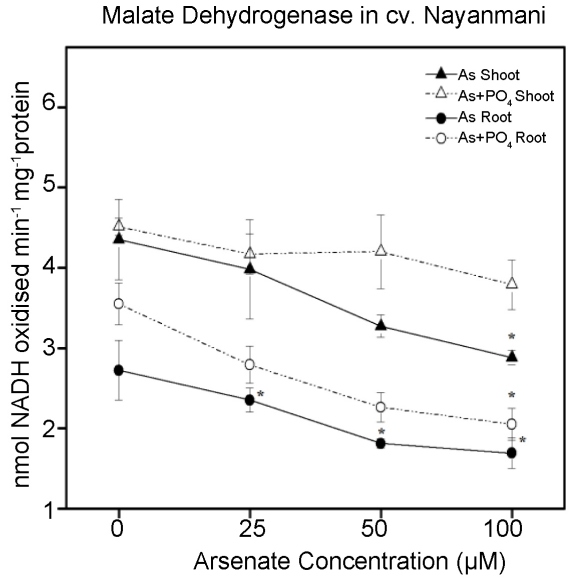

(b)

Figure 8. (a) (b) Effect of arsenate and phosphate applied singly or in combination on the malate dehydrogenase (MDH) activity of 21 days old rice seedlings. The values are means of 3 replicas \pm SE. ${ }^{*}$ indicates statistically significant at $P \leq 0.05$ respectively as compared to water control.

vate, citrate and malate contents of 21 days old arsenic challenged rice seedlings in our study. Pyruvate, the end product of glycolysis is decarboxylated by the enzyme pyruvate dehydrogenase (PDH) forming acetyl coenzyme A which enters the TCA cycle. Citric acid and malic acid are the intermediates in the citric acid cycle, and their synthesis and degradation are closely related with the TCA cycle [34].

In our study we observed an elevation in the organic acid contents in the test seedlings treated with sodium arsenate. The levels of pyruvate, citrate as well as malate increased considerably in cv. IR64, especially in the roots, in comparison to $\mathrm{cv}$. Nayanmani which experienced relatively less elevation in its organic acid contents. Increase in citric acid and malic acid contents were also detected in two rice cultivars studied under Fe stress. Exogenous application of potassium alleviated the said stress to some extent resulting in reduced amounts of citrate and malate [35]. Similar nature of amelioration of arsenic stress has been demonstrated in our study with the joint application of phosphate along with arsenate which resulted in the production of decreased levels of organic acids.

Acids like malic, malonic, citric, fumaric and succinic among others are predominantly found in the root exudates of plants and seem to have a major role in solubilization of nutrients [36]. Organic acid accumulation has been confirmed as one of the mechanisms of stress tolerance in crop roots [37]. Thus, the presence of elevated levels of organic acids indicate the degree of metal toxicity in our test seedlings. In support of our results, [38] also recorded organic acid accumulation in mungbean seedlings under salinity stesss. It has also been documented that several wheat species excrete organic acids from their root apices due to phosphorus (P) deficiency [39]. [40] concluded that in snapbeans under aluminium stress, $\mathrm{P}$ deficiency caused by the formation of Al-phosphate precipitates led to the citric acid secretion. On application of phosphate along with arsenate, the increase in the organic acid contents was much less than arsenate 
treatment alone indicating that phosphate was able to alleviate the metal toxicity to some extent.

\subsection{Effect on the Activities of Krebs Cycle Enzymes}

The mitochondrial electron transport chain is chiefly responsible for the production of intracellular ROS. As a result, the metabolic pathways in the mitochondria become sensitive to the oxidative changes in the intracellular environment. Studies suggest that mitochondria may act as "sensors" in the comprehensive stress response in plants [41]. The Krebs' cycle reactions take place in the matrix of the mitochondria and is composed of a series of enzyme catalyzed reactions. It is the key metabolic pathway that unifies carbohydrate, fat, and protein metabolism. In our study, arsenate stress caused inhibition in the activities of the dehydrogenases of the TCA cycle to variable extents in the tested cultivars, while the activities of citrate synthase and fumarase were induced.

Pyruvate dehydrogenase (PDH), occurring outside TCA cycle, is considered as a primary target for the toxic action of arsenic. Any disruption of action for this enzyme undermines the ability of the cell to meet its energy requirements and could therefore, result in cellular damage and death [42]. A reduction in the activity of PDH has been observed in the test seedlings under arsenate stress, which supports our result of increased accumulation of pyruvate in the above. The level of accumulation of pyruvate as well as the decrease in the activity of PDH was more in IR64 in comparison to cv. Nayanmani.

Citrate synthase (CS) catalyzes the combination of oxaloacetate and acetyl CoA to produce citrate while isocitrate dehydrogenase (IDH) catalyzes the oxidative decarboxylation of isocitrate in the TCA cycle. In our study, an increase in the activity of CS was observed especially in the roots of the test seedlings under arsenate stress. Whereas, inhibition in IDH activity was seen under the same conditions. In a recent study, out of the three IDH isozymes ( $\mathrm{d} 1 \mathrm{~d} 2$ and $\mathrm{d} 3$ ) isolated from cucumber roots, two of them ( $\mathrm{d} 2$ and $\mathrm{d} 3$ ) showed diminished activity under hypoxic stress [41]. Both increase in CS activity and reduction in IDH activity supports the accumulation of citrate as found earlier in the arsenate treated seedlings. [35] also found similar results when they subjected different rice cultivars to Fe stress. Thus, adaptation of plants to metal stress is accompanied by rearrangements in oxidative metabolism as reflected by changes in metabolic pathways resulting in the accumulation of substrates that have an osmotic balancing effect and also results in the alterations of enzymes involved in oxidative metabolism. Joint application of phosphate along with arsenate altered the activities of the above mentioned enzymes in respect of arsenate treatment alone, with the effect being more pronounced in cv IR64.

Mitochondria are major producers of cellular ROS in plants under arsenic challenged conditions, resulting in the accumulation of $\mathrm{H}_{2} \mathrm{O}_{2}$ and thereby inhibiting succinate dehydrogenase (SDH) activity. With arsenate treatment, a reduction in SDH activity was observed in the test seedlings with maximum inhibition experienced in cv. IR64 and least in Nayanmani. Upon entering the cells 
the toxic metals react with the metabolically active mitochondria resulting in the shrinkage of cytochrome $\mathrm{c}$ oxidase and succinate dehydrogenase formation. Thus, the persistant decline in succinate dehydrogenase activity in the present study along with increase of arsenate dose is consistent with this hypothesis. [43] found similar decrease in SDH activity in Aspergillus niger under As toxicity. [41] also reported reduced SDH activity in cucumber roots under hypoxic stress.

The activity of malate dehydrogenase $(\mathrm{MDH})$ considerably decreased in both root and shoot of the arsenate treated test seedlings, with the effect being more pronounced in cv. IR64 than in cv. Nayanmani. [35] reported reduction in MDH activity in rice leaves under $\mathrm{Fe}$ stress. The inhibitory effect of arsenic stress on the enzyme is through conformational changes [44] but increased concentration of the substrate i.e. malate counteracted the damaging effects caused by arsenic and thus may have a protective role [45] under arsenate treatment. Malate is known to regulate the $\mathrm{pH}$ and limit enzymatic browning by chelating and hindering the phenol enzyme activity. On application of arsenate with phosphate the MDH activity improved in comparison to the arsenate treatment alone. Increase in the malate content under arsenic stress also supports the elevation in the activity of the fumarase enzyme in both the cultivars, but to variable extents. Joint application of phosphate along with arsenate witnessed a significant decrease in the fumarase activity, which is also correlated with the level of malic acid measured during these treatments.

\section{Conclusion}

Arsenic pollution of the groundwater is an impending threat in the agriculture based countries of South East Asia as well as many other parts of the world. In our study, arsenic toxicity led to considerable reduction in growth in both the test seedlings, to variable extents. The cultivar Nayanmani showed less morphological alterations in comparison to $\mathrm{cv}$. IR64, which suggests a partial tolerance of the former towards arsenic stress. The intermediates as well as the enzymes of TCA cycle also showed major alterations under arsenic challenged conditions. The activities of pyruvate dehydrogenase, isocitrate dehydrogenase, succinate dehydrogenase and malate dehydrogenase were significantly inhibited, while the levels of organic acids as well as the activities of citrate synthase and fumarase enzymes were enhanced under arsenic treatment alone. These changes were however; more prominent in cv. IR64 than in cv. Nayanmani which supports our earlier morphological result that the latter is partly tolerant to the said metalloid. On joint application of phosphate along with arsenate, the harmful effects of arsenic were ameliorated in both the test seedlings, which showed better growth as well as respiration. Thus, application of external phosphate in arsenic rich soils can be suggested as a possible remedial strategy to combat arsenic contamination in rice fields.

\section{Acknowledgements}

The study was financially supported by the University Grants Commission, New 
Delhi under the Basic Scientific Research (BSR) Fellowship Scheme. The infrastructural facilities were provided by the Centre of Advanced Study, Department of Botany, University of Calcutta.

\section{References}

[1] Singh, N., Ma, L.Q., Srivastava, M. and Rathinasabapathi, B. (2005) Metabolic Adaptations to Arsenic-Induced Oxidative Stress in Pteris vittata $L$ and Pteris ensiformis L. Plant Science, 170, 274-282. https://doi.org/10.1016/j.plantsci.2005.08.013

[2] Zutshi, S., Bano, F., Ningthoujam, M., Habib, K. and Fatma, T. (2015) Metabolic Adaptations to Arsenic-Induced Oxidative Stress in Hapalosiphon fontinalis-339. International Journal of Innovative Research in Science, Engineering and Technology, 2.

[3] Tangahu, B.V., Abdullah, S.R.S., Basri, H., Idris, M., Anuar, N. and Mukhlisin, M. (2011) A Review on HeavyMetals (As, Pb, and Hg) Uptake by Plants through Phytoremediation. International Journal of Chemical Engineering, 939161, 1-31. https://doi.org/10.1155/2011/939161

[4] Machlis, L. (1941) Accumulation of Arsenic in Shoots of Sudan-Grass and BushBean. Plant Physiology, 16, 521-543. https://doi.org/10.1104/pp.16.3.521

[5] Marin, A.R., Pezashki, S.R., Masschelen, P.H., Choi, H.S. (1993) Effect of Dimethylarsenic Acid (Dmaa) on Growth, Tissue Arsenic and Photosynthesis of Rice Plants. Journal of Plant Nutrition, 16, 865-880. https://doi.org/10.1080/01904169309364580

[6] Shri, M., Kumar, S., Chakrabarty, D., Trivedi, P.K., Mallick, S., Misra, P., Shukla, D., Mishra, S., Srivastava, S., Tripathi, R.D. and Tuli, R. (2009) Effect of Arsenic on Growth, Oxidative Stress, and Antioxidant System in Rice Seedlings. Ecotoxicology and Environmental Safety, 72, 1102-1110.

https://doi.org/10.1016/j.ecoenv.2008.09.022

[7] Li, R.C. (2000) Effects of Cadmium and Lead on Physiological and Ultrastructural Features in Tobacco Leaves. Chinese Journal of Plant Ecology, 24, 238-242.

[8] Liu, D. and Wang, Y. (2002) Effect of $\mathrm{Cu}$ and As on Germination and Seedling Growth of Crops. Chinese Journal of Applied Ecology, 13, 179-182.

[9] Yang, S.H., Qu, Z.X. and Wang, H.X. (1986) The Migration and Accumulation of Lead in Rice and Its Influence on the Growth. Acta Ecologica Sinica, 6, 312-322.

[10] López-Bucio, J., Nieto-Jacobo, M.F., Ramírez-Rodríguez, V. and Herrera-Estrella, L. (2000) Organic Acid Metabolism in Plants: From Adaptive Physiology to Transgenic Varieties for Cultivation in Extreme Soils. Plant Science, 160, 1-13. https://doi.org/10.1016/S0168-9452(00)00347-2

[11] Voet, D. and Voet, J.D. (2004) Biochemistry. 3rd Edition, Wiley, NewYork.

[12] Taiz, L. and Zeiger, E. (2002) Plant Physiology. 3rd Edition, Sinauer Associates, Sunderland.

[13] Stoeva, N. and Bineva, T. (2003) Oxidative Changes and Photosynthesis in OAT Plants Grown in AS-Contaminated Soil. Bulgarian Journal of Plant Physiology, 29, 87-95.

[14] Meharg, A. and Macnair, M. (1992) Suppression of the High Affinity PhosphateUptake System: A Mechanism of Arsenic Tolerance in Holcus lanatus L. Journal of Experimental Botany, 43, 519-524. https://doi.org/10.1093/jxb/43.4.519

[15] Grifoni, M., Schiavon, M., Pezzarossa, B., Petruzzelli, G. and Malagoli, M. (2015) Effects of Phosphate and Thiosulphate on Arsenic Accumulation in the Species 
Brassica juncea. Environmental Science and Pollution Research, 22, 2423-2433. https://doi.org/10.1007/s11356-014-2811-1

[16] Bleeker, P.M., Schat, H., Voojis, R., Verleij, J.A.C. and Ernst, W.H.O. (2003) Mechanisms of Arsenate Tolerance in Cystisus striatus. New Phytologist, 157, 33-38. https://doi.org/10.1046/j.1469-8137.2003.00542.x

[17] Zhu, Y.G., Geng, C.N., Tong, Y.P., Smith, S.E. and Smith, F.A. (2006) Phosphate (Pi) and Arsenate Uptake by Two Wheat (Triticum aestivum) Cultivars and Their Doubled Haploid Lines. Annales Botanici, 98, 631-636. https://doi.org/10.1093/aob/mcl139

[18] Sadasivam, S. and Manikam, A. (2008) A Biohemical Methods for Agriculture Sciences. In: Kennedy, J.F. and Mistry, J., Eds., Biochemical Methods, New Age International Publishers, New Delhi.

[19] Saffran, M. and Denstedt, O. (1948) A Rapid Method for Determination of Citric Acid. Journal of Biological Chemistry, 175, 849-855.

[20] Hummel, J.P. (1949) The Fluorometric Determination of Malic Acid. Journal of Biological Chemistry, 180, 1225-1228.

[21] Williams, M. and Randall, D.D. (1979) Pyruvate Dehydrogenase Complex from Chloroplasts of Pisum sativum L. Plant Physiology, 64, 1099-1103. https://doi.org/10.1104/pp.64.6.1099

[22] Srere, P.A., Brazil, H. and Gonen, L. (1963) The Citrate Condensing Enzyme of Pigeon Breast Muscle and Moth Flight Muscle. Acta Chemica Scandinavica, 17, 129-134. https://doi.org/10.3891/acta.chem.scand.17s-0129

[23] Zhou, J., Tian, X., Qiao, L. and Qin, P. (2012) Respiratory Enzyme Activity and Regulation of Respiration Pathway in Seashore Mallow Seedlings under Waterlogging Conditions. Australian Journal of Crop Science, 6, 756-762.

[24] Green, J.D. and Narahara, H.T. (1980) Assay of Succinate Dehydrogenase Activity by the Tetrazolium Method: Evaluation of an Improved Technique in Skeletal Muscle Fractions. Journal of Histochemistry \& Cytochemistry Official, 28, 408-412. https://doi.org/10.1177/28.5.6966645

[25] Gibon, Y., Blaesing, O.E., Hanneman, J., Carillo, P., Hohne, M., Henriks, J.H.M., Palacios, N., Cross, J., Selbig, J. and Stitt, M. (2004) A Robot Based Platform to Measure Multiple Enzyme Activities in Arabidopsis Using a Set of Cycling Assays: Comparison of Changes in Enzyme Activities and Transcript Level during Diurnal Cycles and Prolonged Darkness. Plant Cell, 16, 3304-3325. https://doi.org/10.1105/tpc.104.025973

[26] Kumar, R.G., Shah, K. and Dubey, R.S. (2000) Salinity Induced Behavorial Changes in Malate Dehydrogenase and Glutamate Dehydrogenase Activities in Rice Seedlings of Differing Salt Tolerance. Plant Science, 156, 23-34. https://doi.org/10.1016/S0168-9452(00)00224-7

[27] Lowry, O.H., Rosenbrough, N.J., Farr, A.L. and Randall, R.J. (1951) Protein Measurement with the Folin Phenol Reagent. Journal of Biological Chemistry, 193, 265 275.

[28] Zhao, F.J., Ma, J.F., Meharg, A.A. and McGrath, S.P. (2009) Arsenic Uptake and Metabolism in Plants. New Phytologist, 181, 777-794.

https://doi.org/10.1111/j.1469-8137.2008.02716.x

[29] Garg, N. and Singla, P. (2011) Arsenic Toxicity in Crop Plants: Physiological Effects and Tolerance Mechanisms. Environmental Chemistry Letters, 9, 303-321. https://doi.org/10.1007/s10311-011-0313-7 
[30] Hartley-Whitaker, J., Ainsworth, G. and Meharg, A.A. (2001) Copper and ArsenateInduced Oxidative Stress in Holcus lanatus Clones with Differential Sensitivity. Plant, Cell \& Environment, 24, 713-722. https://doi.org/10.1046/j.0016-8025.2001.00721.x

[31] Li, Q., Wang, B.C., Xu, Y. and Zhu, Y.X. (2007) Systematic Studies of 125 Seed Storage Protein Accumulation and Degradation Patterns during Arabidopsis Seed Maturation and Early Seedling Germination Stages. Journal of Steroid Biochemistry and Molecular Biology, 40, 373-381.

[32] Choudhury, B., Chowdhury, S. and Biswas, A.K. (2011) Regulation of Growth and Metabolism in Rice (Oryza sativa L.) by Arsenic and Its Possible Reversal by Phosphate. Journal of Plant Interactions, 6, 15-24. https://doi.org/10.1080/17429140903487552

[33] Oburger, E., Kirk, G.J.D., Wenzel, W.W. and Puschenreiter, M. (2009) Interactive Effects of Organic Acids in the Rhizosphere. Soil Biology and Biochemistry, 41, 449457. https://doi.org/10.1016/j.soilbio.2008.10.034

[34] Schulze, J., Tesfaye, M. and Litjens, R.H.M.G. (2002) Malate Plays a Central Role in Plant Nutrition. Plant Soil, 247, 133-139. https://doi.org/10.1023/A:1021171417525

[35] Wang, Y.P., Wu, Y.H., Liu, P., Zheng, G.H., Zhang, J.P. and Xu, G.D. (2013) Effects of Potassium on Organic Acid Metabolism of Fe-Sensitive and Fe-Resistant Rices (Oryza sativa L.). Australian Journal of Crop Science, 7, 843-848.

[36] Chang, A.C., Crowley, D.E. and Lee, A. (2004) Assessing Bioavailability of Metals in Biosolids-Treated Soils. International Water Association Publishing, London.

[37] Kochian, L.V., Pellet, D.M. and Grunes, D.L. (1995) Organic Acid Exudation as an Aluminium Tolerance Mechanism in Maize (Zea mays L.). Planta, 196, 788-795. https://doi.org/10.1007/BF01106775

[38] Saha, P., Kunda, P. and Biswas, A.K. (2012) Influence of Sodium Chloride on the Regulation of Krebs Cycle Intermediates and Enzymes of Respiratory Chain in Mungbean (Vigna radiata L.) Seedlings. Plant Physiology and Biochemistry, 60, 214-222. https://doi.org/10.1016/j.plaphy.2012.08.008

[39] Dinkelaker, B., Romheld, V. and Marschner, H. (1989) Citric Acid Excretion and Precipitation of Calcium Citrate in the Rhizosphere of White Lupin (Lupinus albus L.). Plant, Cell \& Environment, 12, 285-292. https://doi.org/10.1111/j.1365-3040.1989.tb01942.x

[40] Miyasaka, S.C., Buta, J.G., Howell, R.K. and Foy, C.D. (1991) Mechanism of Aluminum Tolerance in Snapbeans: Root Exudation of Citric Acid. Plant Physiology, 96, 737-743. https://doi.org/10.1104/pp.96.3.737

[41] Lizhong, H., Bin, L., Xiaomin, L., Lingyun, Y., Yanjuan, Y., Yinghui, Y., Jing, D. and Shirong, G. (2015) The Effect of Exogenous Calcium on Mitochondria, Respiratory Metabolism Enzymes and Ion Transport in Cucumber Roots under Hypoxia. Scientific Reports, 5, 11391. https://doi.org/10.1038/srep11391

[42] Samikkannu, T., Chen, C.H., Yih, L.H., Wang, A.S., Lin, S.Y., Chen, T.C. and Jan, K.Y. (2003) Reactive Oxygen Species Are Involved in Arsenic Trioxide Inhibition of Pyruvate Dehydrogenase Activity. Chemical Research in Toxicology, 16, 409-414. https://doi.org/10.1021/tx025615j

[43] Mukherjee, A., Das, D., Mondal, S.K., Biswas, R., Das, T.K., Boujedaini, N. and Khuda-Bukhsh, A.R. (2010) Tolerance of Arsenate-Induced Stress in Aspergillus niger, a Possible Candidate for Bioremediation. Ecotoxicology and Environmental Safety, 73, 172-182. https://doi.org/10.1016/j.ecoenv.2009.09.015 
[44] Duporque, D. and Kun, E. (1969) Malate Dehydrogenase of Ox Kidney. Two Substrate Kinetics and Inhibition Analyses. European Journal of Biochemistry, 7, 242252.

[45] Kalir, A. and Poljakoff-Mayber, A. (1975) Malic Dehydrogenase from Tamaric Roots: Effects of Sodium Chloride In Vivo and In Vitro. Plant Physiology, 55, 155162. https://doi.org/10.1104/pp.55.2.155

Submit or recommend next manuscript to SCIRP and we will provide best service for you:

Accepting pre-submission inquiries through Email, Facebook, LinkedIn, Twitter, etc. A wide selection of journals (inclusive of 9 subjects, more than 200 journals)

Providing 24-hour high-quality service

User-friendly online submission system

Fair and swift peer-review system

Efficient typesetting and proofreading procedure

Display of the result of downloads and visits, as well as the number of cited articles Maximum dissemination of your research work

Submit your manuscript at: http://papersubmission.scirp.org/

Or contact ajps@scirp.org 